\title{
TACKLING UNDECLARED WORK IN BULGARIA: KNOWLEDGE- INFORMED POLICY RESPONSES
}

\author{
GREY Policy Brief, No. 1, 2017
}

Participation in undeclared work (UDW) is widespread in Bulgaria. Some $23 \%$ of adult Bulgarians have knowingly purchased from the undeclared economy ${ }^{1}$. Nearly 1 in 10 of the adults have worked in the undeclared economy ${ }^{2}$, while almost 1 in 7 of the employed have received envelope wages, with the mean amount underreported at 30\% of their net income ${ }^{3} A$ third of the population has declared to use personal relations to circumvent formal rules ${ }^{4}$. This points out to a serious economic, social and rule of law problem. Trust among citizens and towards the authorities is low, providing an excellent breeding ground for corruption and crime. Bulgarian authorities need to embark on a comprehensive agenda of understanding and tackling undeclared work. Given the complex character of undeclared work in Bulgaria, this

Authors: Ruslan Stefanov, Colin C. Williams and Peter Rodgers

1 Williams, C., and Bezeredi, S. 2017 Explaining consumers' motives for purchasing from the informal economy: some lessons from a study of Bulgaria, Croatia and FYR Macedonia, GREY Paper, University of Sheffield. ${ }^{2}$ Williams, C. and Yang, J. 2017. Evaluating competing perspectives towards undeclared work: some lessons from Bulgaria, GREY Paper, March 2017.

${ }^{3}$ Williams, C. and Yang, C., 2017. Tackling falselydeclared salaries in Bulgaria: evidence from a 2015 survey, GREY Paper, Economic Alternatives,

${ }^{4}$ Williams, C. and Yang, C., 2017. Evaluating the use of personal networks to circumvent formal processes: a case study of 'vruzki' in Bulgaria, South East European Journal of Economics and Business, 12(1): 57-67. policy brief gives policy recommendations, which emphasise curative, preventative and commitment measures in addition to the continuous increase in repressive measures.

\section{KEY POINTS}

Undeclared work is socially accepted and widely practiced in Bulgaria. The undeclared economy is estimated at roughly a third of GDP. Nearly one in ten people do some undeclared work.

$>$ Undeclared work is motivated primarily by lack of trust between the people and the authorities. It involves mostly people who voluntarily exit the declared economy but also those that are excluded.

$>$ The conventional repressive approach to tackling undeclared work has exhausted its effects in Bulgaria. It should be complemented with more curative, preventative and commitment policies.

$>$ Policymakers should consider not just the rational but also the social actor approach which tackles trust issues and the asymmetry between formal and informal rules. Authorities should continue modernising institutions and should increase social spending and public awareness campaigns. 


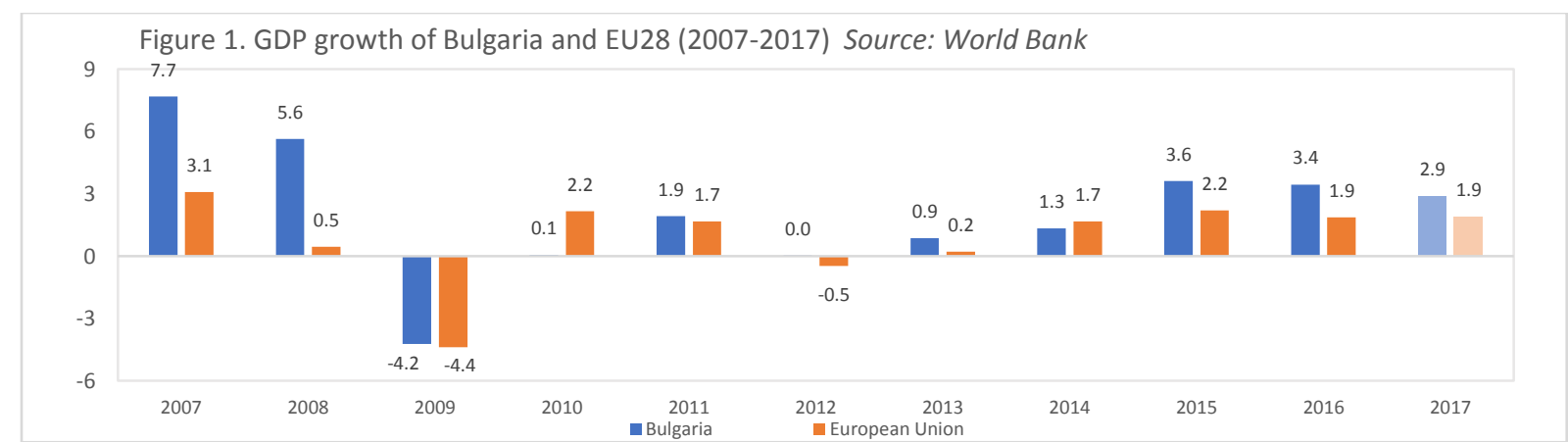

\section{Macroeconomic overview}

Understanding the economic development and constraints of Bulgaria provides important background to the discussion of the forms and characteristics of undeclared work, and the country's available policy options for tackling the phenomena.

In 2007, Bulgaria joined the European Union. While preparing for membership, the country successfully implemented many reforms, leading to a better business environment and more investments. Advances were made in comparison to the chaotic transition in the 1990s. However, since EU accession, progress has deteriorated due to inefficient implementation of reforms and the global recession. These developments are illustrated in the decrease in business trust in formal institutions (Figure 2). Weak law enforcement and corruption remain obstacles to doing business in Bulgaria. Despite these problems in formal institutions, the competitiveness of the economy has improved in 2016 after climbing 5 places in the IMD World Competitiveness Yearbook. ${ }^{5}$

GDP growth has accelerated and outstrips the EU average. (Figure 1) ${ }^{6}$ In Q3 2016, Bulgaria registered the highest growth among EU members (0.9\%). In 2016, private consumption and strong exports were the

${ }^{5}$ CSD, The hidden economy in Bulgaria: 2015 - 2016,

Sofia: Center for the Study of Democracy

${ }^{6}$ The data for 2017 is a projection and taken from

European Commission's 2017 Country Report. main drivers of growth. ${ }^{7}$ However, in 2017 net exports are expected to deteriorate because of increasing demand for imports. Despite an expected increase in investments due to the pick-up of the new programming period for EU funds, potential growth will remain subdued due to the slow implementation of EU funds and related policy reforms, and surging oil prices. ${ }^{8}$

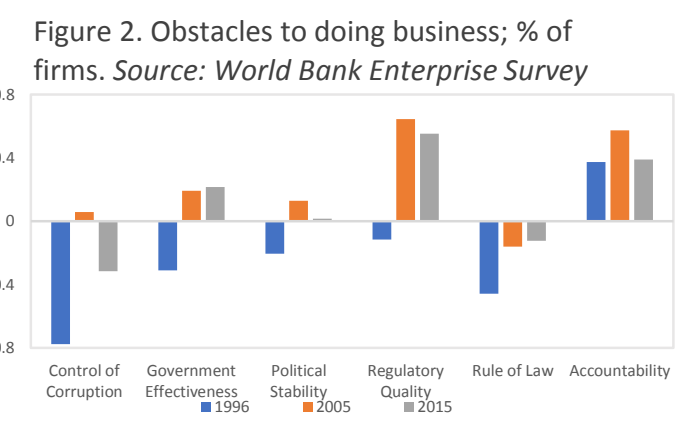

The Bulgarian labour market continues to have structural weaknesses, in spite of a quickly subsiding unemployment. In 2016, the rate of unemployment $(7.6 \%)$ has fallen below the EU average (8.6\%). However, there is a high inactivity level and higher than the EU average long-term unemployment (Figure 3 ), as well as high youth unemployment, all of which indicate potential for high levels of undeclared work. There is also a notable decrease in both labour supply and its quality $^{9}$, evident in the large share of underachievers in the PISA tests. While 20\%

\footnotetext{
${ }^{7}$ European Commission, Country Report Bulgaria 2017, 28 Feb 2017, Available at:

https://ec.europa.eu/info/sites/info/files/2017european-semester-country-report-bulgaria-en 3.pdf ${ }^{8}$ Ibid.

${ }^{9}$ Ibid.
} 
of labour market entrants are Roma, ${ }^{10}$ many of them are not well educated and lack the necessary skills. Labour market policies should strive to integrate Roma people more actively.

Figure 3. Long-term unemployment, as

$\%$ of total unemployment Source: Ibid

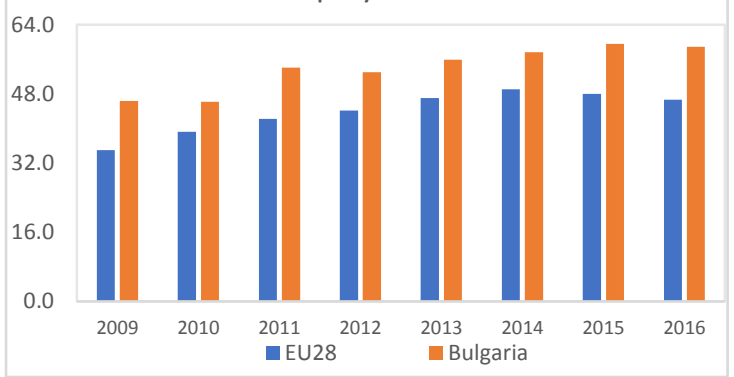

On a more positive note, government debt and deficits are expected to decline further, which will provide the resources necessary for tackling undeclared work in a more comprehensive manner (Figure 4). While higher public wages will increase expenditures in 2017, revenues will improve due to a better economic perspective. Debt is also expected to decrease further, because of cash buffers and improved debt financing conditions. However, the payment of the debts of stateowned enterprises, which operate on a loss, is not considered in the general government debt, but might affect the fiscal stability, in particular in the energy sector.

Figure 4. Government debt and deficit

30

(\%) as part of GDP Source: Eurostat

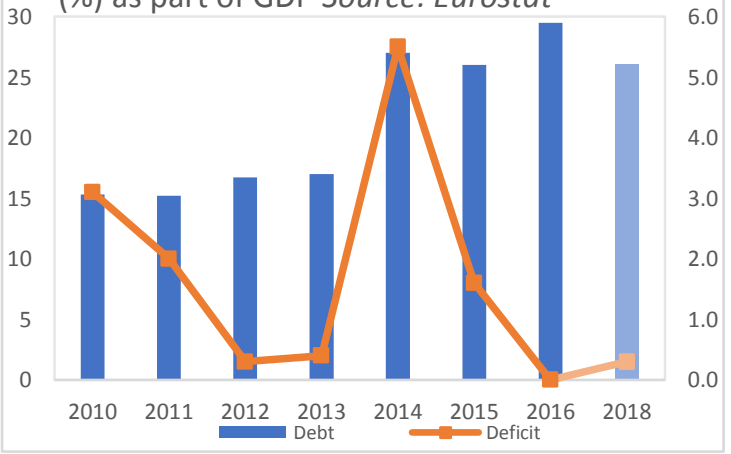

\section{Policy Context}

The lion's share of policies utilized in the EU and Bulgaria are aimed at repressing undeclared work. Such measures are based

\footnotetext{
${ }^{10} \mathrm{Ibid}$
}

upon the rational actor approach and assume that people engage in the undeclared economy as long as the benefits from doing so exceed the costs. If the costs are raised, they will stop taking part. Examples of such policies include increasing the sanctions for engaging into undeclared work and improving the surveillance system over the undeclared economy ${ }^{11}$.

\section{Definitions}

Undeclared work is defined by the European Commission as 'any paid activities that are lawful as regards their nature, but are not declared to the public authorities, taking into account the differences in their regulatory systems among Member States'. This definition implies that if a good or service such as drugs is illegal, it is part of the criminal world, not part of the undeclared economy.

An envelope wage is a second wage paid to the employee, separately from the officially declared wage, without paying the required tax and social contributions.

Regardless of methodology, the share of the undeclared economy in Bulgaria remains a substantial, albeit declining, one third of GDP. (Figure $5^{12}$ ), and is among the highest in the EU.

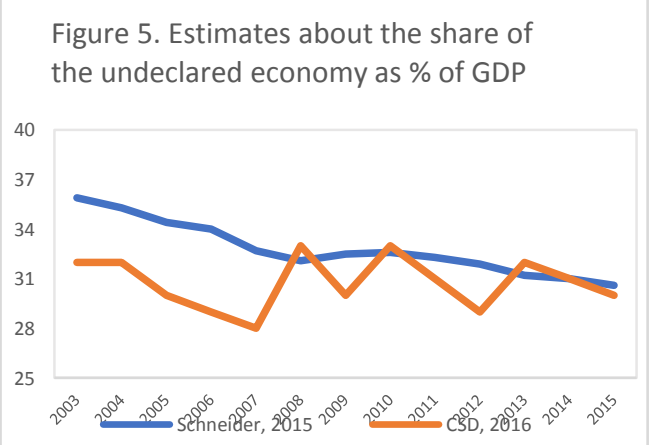

\footnotetext{
${ }^{11}$ Williams, C.C. 2014. Policy approaches towards undeclared work: conceptual framework, GREY Working Paper 4, University of Sheffield Management School, University of Sheffield.

${ }^{12}$ Schneider, F. Size and Development of the Shadow Economy of 31 European and 5 other OECD Countries from 2003 to 2015: Different Developments, January 2015, Available at:

http://www.econ.jku.at/members/Schneider/files/ publications/2015/ShadEcEurope31.pdf and CSD, Hidden Economy Indexes in Bulgaria 2002-2015, 2016, Available at: http://www.csd.bg/artShow.php?id=17759
} 
Due to its magnitude, the most effective policies should be used. The use of repressive measures has been prioritized in the past two decades but as visible from data, their effect has been marginal since the country joined the EU, indicating the need for applying a wider range of policy approaches. ${ }^{13}$ The government needs to consider the other three types of policies used to tackle undeclared work:

$>$ Preventative policies seek to reduce noncompliance before it has occurred.

$>$ Curative polices strive to support firms and people, who work on an undeclared basis, to formalize their activities.

$>$ Commitment policies seek to increase citizens' tax morale and foster their voluntary compliance.

Given the need to revisit the traditional approaches not only in terms of available policies but also in terms of understanding the underlying issues, policy makers need to also seriously challenge the validity of the rational actor approach and instead employ the more modern and European-based social actor approach. This view suggests that people engage in undeclared work because of the 'normalisation' of undeclared work in society and the non-alignment between formal and informal institutions. The policies based on this approach aim at increasing citizens' trust in formal institutions and challenging the normalization of undeclared work. In particular, these are mostly commitment policies such as education campaigns about the value of taxation and active anticorruption campaigns. In comparison to the rational actor approach, this perspective is

\footnotetext{
${ }^{13}$ See GREY Project working papers available at: http://www.grey-project.group.shef.ac.uk/publications/ In particular Dzhekova, R., and Williams, C., 2014, Tackling the Undeclared Economy in Bulgaria: a Baseline Report, Sheffield University Management School, University of Sheffield, April 2014.
}

repeatedly found to have more empirical support as effective. ${ }^{14}$

The social actor approach has two pillars in building trust in society and the economy:

$>$ Horizontal trust is the idea that people are more likely to engage in the undeclared economy when they perceive that a larger share of the population does so.

$>$ Vertical trust is the idea that people do undeclared work when they have low tax morale, i.e. perceive that there is a big gap between formal and informal institutions. ${ }^{15}$ The lower their perception about formal institutions' accountability, the lower their tax morale and the higher their vulnerability to undeclared work.

\section{Undeclared work}

Bulgarians see undeclared work as deeply ingrained in their society. According to GREY data, nearly one in five citizens has purchased a good on undeclared basis. Moreover, nearly one in ten does some undeclared work, and one in seven employed receives an envelope wage, which is on average $30 \%$ of their net income.

The social acceptability roots of undeclared work are attributed primarily to the transition from a centrally planned to market economy in Bulgaria and in Southeastern Europe. The unruly privatization and 'informalisation' of huge corruption during the period resulted in

\footnotetext{
${ }^{14}$ Ibid. Especially GREY Project Working paper 8: Kojouharov, A., and Williams, C., 2016, Evaluating policy measures to tackle undeclared work: the role of stakeholder collaboration in building trust and improving policy-making, University of Sheffield Management School, University of Sheffield, 2016.

${ }^{15}$ Tax morale is the intrinsic motivation of citizens to pay taxes., and displays the extent to which formal rules and institutions correspond to the socially accepted norms. For a detailed description, see Franic, Josip and Colin C Williams, Illegitimate Practices in Croatia, Sheffield University Management School and Institute of Public Finance, Zagreb, Working Paper No. 9 GREY Project.
} 


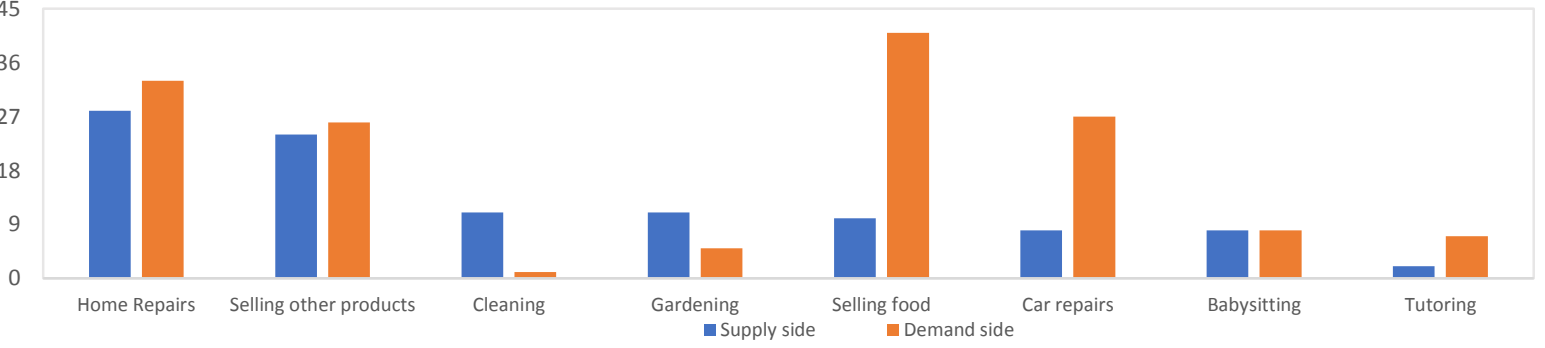

a negative perception of both the formal economy and institutions in the eyes of the public. $^{16}$ Moreover, due to the chaotic transition, many Bulgarians lost their job and saw undeclared work as the only means of survival.

In order to fully grasp undeclared work, the division between its demand and supply side should be understood. The demand side is the engagement in the purchase of undeclared goods and services. The supply side consists of the people who are doing undeclared work.

There is a correspondence between the main sectors on both sides. (Figure $6^{17}$ ) On the demand side, the most common activities are the purchase of domestic food (41\%) and of other products such as goods associated with one's hobby (26\%) and also home (33\%) and car $(27 \%)$ repairs. On the supply side, car repairs and the sale of domestic products occur less often but remain quite common, whereas cleaning (11\%) and gardening (11\%) are also important activities in which people do not declare their income. Exploring these activities is vital, because it presents the sectors, on which policies should be focused.

Undeclared work is unequally spread around different regions in Bulgaria. (Figure 7$)^{18}$

\footnotetext{
${ }^{16}$ Nonchev, A. (ed), 2011. The Hidden Economy in Bulgaria and the Global Economic Crisis, Center for the Study of Democracy, Sofia, 2011.

${ }^{17}$ European Commission, Undeclared work in the European Union, Eurobarometer 402, Available at: http://ec.europa.eu/commfrontoffice/publicopinion/arc hives/ebs/ebs 402 en.pdf

${ }^{18}$ The reason why the share of demand side is bigger is that just $9 \%$ do undeclared work (supply side), whereas $23 \%$ purchase undeclared goods (demand side)
}

People in the Northcentral and Northwest seem to be more engaged in undeclared work. Those are the less developed parts in Bulgaria and, according to Eurostat, are the least developed two regions in the whole EU. The long-term unemployment as part of total unemployment in the Northwest was the fourth highest in the EU (76.5\%). In the North central, it is $66.2 \%$. There is also high demand for undeclared goods in the Southcentral region. However, as undeclared work has been shown to be driven not only exclusion but also self-motivation, policy responses should be well calibrated in the different regions.

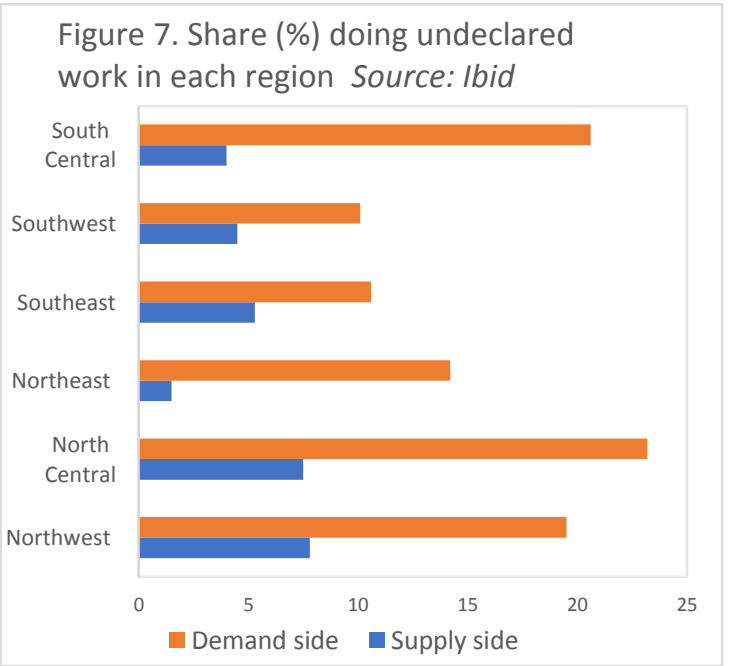

\section{Demand side}

The rational choice approach cannot explain fully why people purchase goods on an undeclared basis. (Figure 8$)^{19}$ Only one in two purchases on undeclared basis were because of a lower price (51\%). The failure of the

\footnotetext{
${ }^{19}$ Williams, C. and Bezeredi, S., Explaining consumers' motives for purchasing from the informal economy: some lessons from a study of Bulgaria, Croatia and FYR Macedonia, GREY Project Paper
} 
formal economy, which citizens declare as the primary reason for buying in the undeclared economy, refers to citizens exiting the formal economy not simply due to the bad business environment, but also because their values differ from the formal laws ${ }^{20}$. This means that the lack of vertical trust (in the institutions of authority) is a stronger rationale for purchasing undeclared products $(57 \%)$ than the lower price. While the social actor approach cannot explain the demand side entirely, it should at the very least supplement the traditional rational approach.

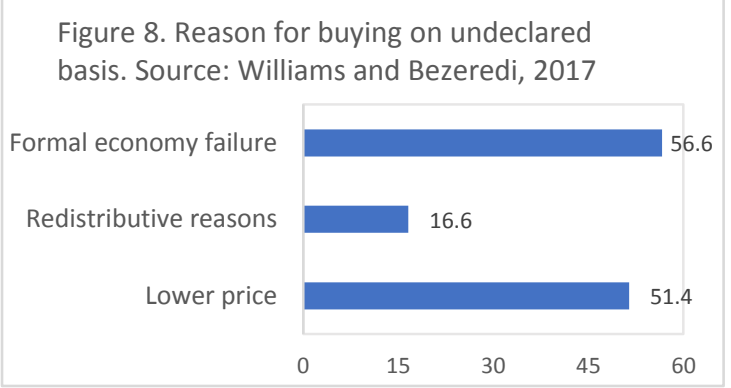

The lack of horizontal trust seems also to be associated with purchases on an undeclared basis in Bulgaria. Bulgarians might be spending just 118 EUR on undeclared goods and services annually, but in comparison to the average income (just above 500 EUR in 2017) the percentage is much higher than the EU average in relative terms. ${ }^{21}$ Moreover, it is much more widespread in Bulgaria than in the EU to purchase undeclared goods from strangers. (Figure 9) Given that Bulgarians have such illegal dealings with strangers, it must be socially acceptable to engage in such practices.

\footnotetext{
${ }^{20}$ Ibid.

${ }^{21}$ Dzhekova, Rosistsa and Williams, Colin, Tackling the Undeclared Economy in Bulgaria, Sheffield University Management School, 2014 GREY Working Paper No.1, Available at: http://www.greyproject.group.shef.ac.uk/ wp-content/ uploads/2014/04/Tackling-the-UndeclaredEconomy-in-Bulgaria-April-2014.pdf
}

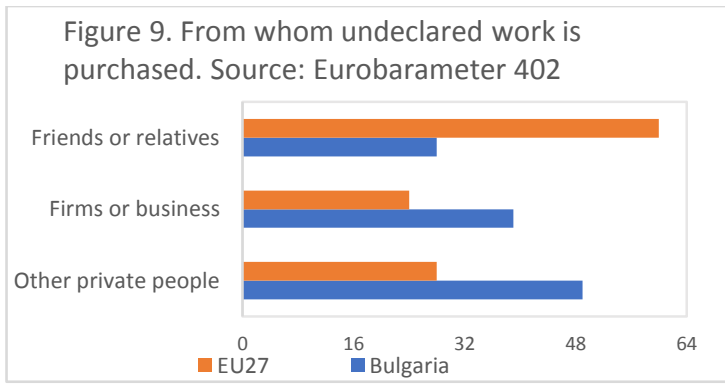

\section{Supply side}

GREY research has demonstrated that workers on the supply side of undeclared work can be generally divided into three types: ${ }^{22}$

> “Lower-tier" exclusion-driven workers: this group exits the formal economy involuntarily and less affluent.

$>$ "Upper-tier" exit-driven workers: this group does undeclared work voluntarily, mostly driven by the lack of vertical and horizontal trust.

$>$ Mixed exclusion and exit driven workers who form the continuum between the above two groups.

For every exclusion-driven worker in Bulgaria, there are 4.8 exit-driven. Thus, many more workers exited because they considered it acceptable to do undeclared work. The existence of two tiers is confirmed in Table $1 .^{23}$ Undeclared work is found among the poorest one fifth (17\%) and the richest fifth (20\%).

\begin{tabular}{|c|c|c|c|c|}
\hline No income & <350EUR & $\mathbf{3 5 0 - 7 0 0 ~ E U R ~}$ & $\mathbf{7 0 0 - 1 k}$ EUR & >1000 EUR \\
\hline $17.40 \%$ & $7.70 \%$ & $8.80 \%$ & $7.10 \%$ & $20.40 \%$ \\
\hline
\end{tabular}

Table 1. Income and share doing undeclared work. Source: Williams and Yang, 2017a

Increasing surveillance, a common repressive measure undertaken in cases of undeclared work, seems to be associated with less undeclared work in Bulgaria. Similarly, increasing the risk of detection through more

\footnotetext{
${ }^{22}$ Williams, Colin and Bezeredi, Slavko, Explaining and tackling the informal economy: a dual informal labour market approach, GREY Project Paper.

23 Williams, Colin and Yang Junhong, Evaluating competing perspectives towards undeclared work: some lessons from Bulgaria, 2017a, GREY Project Paper
} 
regular inspections decreases engagement with undeclared work (Table 2).

\begin{tabular}{|l|l|}
\hline Detection risk & Share \\
\hline Very small & $15.10 \%$ \\
\hline Fairly small & $8.10 \%$ \\
\hline Fairly high/Very high & $7.40 \%$ \\
\hline \multicolumn{2}{|l|}{ Table 2. Relation between detection risk and } \\
\hline doing undeclared work. Source: Ibid \\
\hline
\end{tabular}

However, another widely used repressive measure, the increase in sanctions, does not seem to have any significant impact on undeclared wages in Bulgaria. While people who consider the sanctions as entailing both $\mathrm{s}$ fine and prison are less likely to do undeclared work, (8.3\%) the difference seem negligible (9.8\%). One possible explanation might be the very high systemic levels of corruption, which simply transform higher fines into higher corruption payments, but no deterrence. Moreover, Bulgarians themselves do not support such repressive measures as they consider them as less effective than curative, commitment and preventive measures. ${ }^{24}$

\begin{tabular}{|l|c|c|}
\hline Sanctions & $\begin{array}{l}\text { Tax or social security } \\
\text { contributions due }\end{array}$ & $\begin{array}{l}\text { Plus a fine/ } \\
\text { Prison }\end{array}$ \\
\hline Share & $9.80 \%$ & $8.30 \%$ \\
\hline
\end{tabular}

Table 3. Relation between sanctions and doing undeclared work. Source: Ibid

By contrast, a clear relation exists between tax morale and undeclared work. (Figure 10) A rigorous statistical test confirms the existence of such a correlation, but does not find a significant association between undeclared work and detection risk or higher sanctions. ${ }^{25}$

\footnotetext{
${ }^{24}$ Dzhekova, Rosistsa and Williams, Collin, Tackling the Undeclared Economy in Bulgaria, Sheffield University Management School, 2014 GREY Working Paper No.1, Available at: http://www.grey-project.group.shef.ac.uk/ wp-content/uploads/2014/04/Tackling-the-UndeclaredEconomy-in-Bulgaria-April-2014.pdf

25 Williams, Colin and Yang, Junhong, Evaluating competing perspectives towards undeclared work: some lessons from Bulgaria, 2017a, European Commission
}

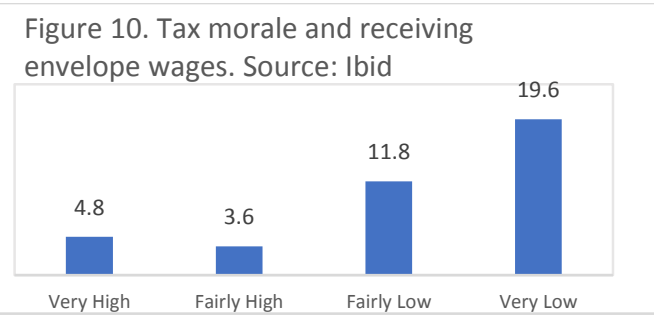

Given the results, the social actor approach and commitment measures should at the very least supplement the rational actor approach and repressive measures in Bulgaria in any future government approach.

\section{Envelope wages}

Detecting employees whose salary is underdeclared is harder than tracking people engaged in fully undeclared work (i.e. without contracts), because most envelope wages are agreed verbally. During the transition period, it was common in many sectors for workers to be officially paid the minimum wage, but to receive also an envelope wage. Afterwards, the introduction of new labour legislation during the early 00s and before EU accession deterred successfully this practice. Currently, some one in seven employees declares that they receive an envelope wage. $^{26}$ Such practices are most common in sectors such as agriculture, construction and hospitality

Contrary to popular belief, it is not always the employer who coerces the employees to under-report the wage. (Table 4) In nearly one third of cases, the employee $(31.4 \%)$ has an active role. When fighting undeclared work, policymakers should consider also workers' incentives. Simply raising sanctions to stop employers from offering envelope wages will not suffice. Table 4 also illustrates the lack of horizontal trust, as some employees do not see a problem with such illegal practices, although they are the ones ultimately being hurt.

\footnotetext{
${ }^{26}$ Williams, Colin and Yang, Junhong (2017b), Tackling falsely-declared salaries in Bulgaria: evidence from a 2015 survey, European Commission.
} 


\begin{tabular}{|c|c|c|c|c|}
\hline Proposer & Employer & Joint & Employee & detection and punishment. While it seems \\
\hline Share & $65.3 \%$ & $29.1 \%$ & $2.3 \%$ & reasonable to continue with repressive \\
\hline
\end{tabular}

Many employees do not seem to have a problem with such an arrangement (Table 5). Two thirds (65\%) are happy or neutral with such arrangements and prefer not to have their wage declared. They do not think that formal institutions of government will use their contributions appropriately, illustrating the lack of vertical trust. To change this attitude, tax morale, not detection risk, must be addressed.

\begin{tabular}{|l|l|l|l|}
\hline Level of happiness & Happy & Neutral & Unhappy \\
\hline Share & $31.2 \%$ & $33.7 \%$ & $27.4 \%$ \\
\hline
\end{tabular}

Table 5. The level of happiness of people who receive envelope wages. Source: Ibid

Repressive measures do not seem to be effective at fighting envelope wages (Table 6). While people who consider the detection risk as 'fairly small' (16\%) are less likely to receive envelope wages than people who consider it as 'very small' (12\%), the association do not hold for people who consider the risk as 'fairly/very high' (21\%) as this group is more likely than the other two to engage in this illegal practice. Improving the surveillance system will not deter Bulgarians from taking envelope wages. Similarly, increasing sanctions also does not have a positive effect on envelope wages. ${ }^{27}$

\begin{tabular}{|l|c|c|c|}
\hline Detection risk & $\begin{array}{c}\text { Very } \\
\text { Small }\end{array}$ & $\begin{array}{c}\text { Fairly } \\
\text { Small }\end{array}$ & $\begin{array}{c}\text { Fairly/ } \\
\text { Very High }\end{array}$ \\
\hline Share & $16.4 \%$ & $11.9 \%$ & $20.9 \%$ \\
\hline
\end{tabular}

Table 6. The relation between detection risk and envelope wages. Source: Ibid

Tax morale is found to be associated with envelope wages (Figure 11). Increasing the tax morale of Bulgarians leads to a smaller likelihood of receiving such wages. Policymakers should consider these findings seriously and implement more comprehensive measures rather than simply focusing on

${ }^{27}$ Ibid. 
An effective policy approach towards undeclared work requires continuous modernisation of the institutional framework to address the positive attitude towards such illegal activities in Bulgaria. In order to conclusively establish the most effective measures, and given that currently there is not enough coordination between the main government bodies ${ }^{30}$ involved in tackling undeclared work, a central organization should be set up to ensure their cooperation and gather the relevant data. It should also collaborate with local NGOs and other foreign researchers which have studied undeclared work for long periods. The European Platform Tackling Undeclared Work should be an important ally to the Bulgarian government in this relation.

While less emphasis should be placed upon the measures traditionally used, such repressive policies should not be fully abandoned, but rather supplemented with commitment, preventative and especially curative policies. Improving people's horizontal and vertical trust should become a priority for policymakers, as findings have indicated that both dimensions of trust are very weak in Bulgaria, which harms the enforceability of policy measures.

\section{Vertical trust}

On a macro level, Bulgarian policy makers need to tackle urgently high-level corruption and strengthen the rule of law to restore trust in public institutions. There seems to be two important policy elements to this. Firstly, Bulgaria needs to revamp its anti-corruption policy, which has been essentially defunct for the past five years. The currently debated

\footnotetext{
${ }^{30}$ For a details on these organization, see chapter 6 of Dzhekova, Rosistsa and Williams, Collin, Tackling the Undeclared Economy in Bulgaria, Sheffield University Management School, 2014 GREY Working Paper No.1, Available at: http://www.grey-

project.group.shef.ac.uk/wp-content/uploads/2014/04/ Tackling-the-Undeclared-Economy-in-Bulgaria-April2014.pdf
}

centralisation of anti-corruption efforts would require a lot of political will to implement in particular in guaranteeing the operational strength and independence of any newly created anticorruption agency from the interests of the incumbent political elite. Secondly, the long-awaited judicial reform does not seem to deliver the expected results. It will not only ensure the transparency of formal institutions, but restore trust in the political elite.

The persecution of corrupt officials should be managed more effectively. They should become aware that there are costs to taking bribes and be deterred from such practices. A sense of accountability will be restored in citizens. More importantly this will restore credibility in the repressive functions of policy, which currently seems not to be the case. Improving trust overall would have highly beneficial effects on reducing undeclared work.

Before implementing a policy, surveys and impact research should be conducted to find out how Bulgarians are actually affected by a certain decision. In this way, vertical trust will be restored as people will see that their opinions actually matter to policymakers.

On a micro level, public servants should try to treat citizens more fairly. In particular, the tax office tends to be very intolerant of people who have made mistakes while filing their reports. If this attitude is abandoned, people will restore their trust in formal institutions and also evade fewer taxes.

The procedures for citizens' formalizing their undeclared activities should be made easier. Bulgarians in such situations should be provided with more support and be actively encouraged to do so. The Bulgarian authorities should be well aware that most of the people have gone informal on their own initiative but should not forget that still more than one in ten have been pushed out, which means measures should be carefully 
calibrated not to victimize already excluded people.

\section{Horizontal trust}

Bulgarians should be educated about the benefits of paying their contributions. They should be aware how their money is spent on public goods such as infrastructure or schools, and should be convinced that every year in and out their taxes buy better quality. This could be achieved via sending letters to people directly on what has been done with their taxes, or designing billboards about the infrastructure built with public money, or introducing a specific subject in the school curriculum.

Bulgarians should be educated about the costs of not paying their contributions.
Citizens should be aware about dependence on the state for old-age or disability pensions, which is funded by their contributions.

The widespread use of personal connections should be deterred. In that way, citizens' sense of meritocracy would be restored. It is a remnant of the past, which persists, noting the slow pace of reform of the Bulgarian economy.

While certain institutions like the tax authorities seem to have realized some of these recommendations, and with EU help have started implementing some of them, a lot more needs to be done for Bulgaria to overcome the detrimental effect of low trust in public institutions.

\section{References: GREY Project Further Reading}

Baric, M., Franic, J. and Polak, M. (2016). Tackling undeclared entrepreneurship in a transition setting: the case of Croatia. International Journal of Entrepreneurship and Small Business, 28(2/3), $255-274$.

Bejaković, P. (2016) Informal Economies in Post-Socialist Spaces - Practices, Institutions and Networks. Financial Theory and Practice. 40 (1), 149-155

Bejaković, P. (2016) A revision of the shadow economy in Croatia: causes and effects, Economic Research-Ekonomska Istraživanja, 28:1, 422-440:

Bejaković, P. (2016) The Evasion of Retirement Insurance Contributions in Croatia, Studies of Transition States and Societies, 8 (2016) , 1; 20-35

Bezeredi, S. and Williams, C.C. (2017) Illegitimate economic practices in FYR Macedonia, GREY Working Paper no. 10, Sheffield University Management School, University of Sheffield, Sheffield

Dzhekova, P. and Williams, C.C., (2014). Tackling the Undeclared Economy in Bulgaria: A Baseline Report, GREY Working Paper No.1, Sheffield University Management School, University of Sheffield

Dzhekova, P., Franic, J., Mishkov, L and Williams, C.C., (2014). Tackling the Undeclared Economy in FYR Macedonia: A Baseline Assessment, GREY Working Paper No. 3, Sheffield University Management School, University of Sheffield

Franic, J. and Williams, C.C., (2014). Undeclared Work in Croatia: A Baseline Assessment, GREY Working Paper No. 2, Sheffield, University Management School, University of Sheffield

Franic, J. and Williams, C.C., (2017). Illegitimate Economic Practices in Croatia, GREY Working Paper No. 9, Sheffield University Management School, University of Sheffield, Institute of Public Finance, Zagreb

Horodnic, I.A., Rodgers, P., Williams, C.C. and Momtazian. L. (Eds.) (2018) The Informal Economy: exploring drivers and practices, Routledge, London. 
Kojouharov, A. and Williams, C.C., (2015). Evaluating Policy Measures to Tackle Undeclared Work: The Role of Stakeholder Collaboration in Building Trust and Improving Policy-Making, GREY Working Paper No. 8, Sheffield University Management School, University of Sheffield.

Polak, M., Mishkov, L. and Williams, C.C., (2015). Designing Focus Groups and Experiments to Evaluate Policy Approaches and Measures for Tackling Undeclared Work, GREY Working Paper No. 6, Sheffield University Management School, University of Sheffield

Polese, A., Williams, C.C., Horodnic, I. and Bejakovic, P. (Eds.) The Informal Economy in Global Perspective: varieties of governance, Palgrave Macmillan, Basingstoke,

Williams, C.C. (2014). Policy Approaches Towards Undeclared Work, GREY Working Paper No. 4, Sheffield University Management School, University of Sheffield

Williams, C.C. (2015). Designing Survey Methods to Evaluate the Undeclared Economy: A Review of the Options, GREY Working Paper No. 7, Sheffield University Management School, University of Sheffield

Williams, C.C. (2017) "Tackling employment in the informal economy: a critical evaluation of the neo-liberal policy approach", Economic and Industrial Democracy: an International Journal, Vol. 38, No.1, pp. 145-169

Williams, C.C. and Bezeredi, S., (2017). Illegitimate Economic Practices in FYR Macedonia, GREY Working Paper No. 10, Sheffield University Management School, University of Sheffield

Williams, C.C. and Bezeredi, S. (2017) "Evaluating the use of personal connections to bypass formal procedures: a study of vrski in FYR Macedonia", UTMS Journal of Economics, Vol. 8, No. 2,

Williams, C.C. and Dzhekova, R., (2014) "Evaluating the cross-national transferability of policies: a conceptual framework", Journal of Developmental Entrepreneurship, Vol. 19, No. 4., 1450022

Williams, C.C. and Franic, F. (2015): 'Tackling the Propensity towards Undeclared Work: Some Policy Lessons from Croatia', South East European Journal of Economics and Business, Vol. 10(1), 18-31.

Williams, C.C. and Franic, J. (2016) "Beyond a deterrence approach towards the undeclared economy: some lessons from Bulgaria", Journal of Balkan and Near Eastern Studies, Vol. 18 No. 1, pp. 90-106.

Williams, C.C. and Franic, J. (2016) "Explaining participation in the informal economy in post-socialist societies: a study of the asymmetry between formal and informal institutions in Croatia", Journal of Contemporary Central and Eastern Europe, Vol. 24, No. 1, pp. 51-65.

Williams, C.C. and Franic, J. (2017) "Tackling the illegitimate under-reporting of salaries in Southeast Europe: some lessons from a 2015 survey of Bulgaria, Croatia and FYR Macedonia", Eastern Journal of European Studies, Vol. 8, No. 1, pp. 5-28.

Williams, C.C. and Yang, J. (2017) "Evaluating the use of personal networks to circumvent formal processes: a case study of vruzki in Bulgaria", The South East European Journal of Economics and Business, Vol. 12, No. 1, pp. 57-67.

Williams, C.C. and Yang, J. (2017) "Tackling falsely-declared salaries in Bulgaria: evidence from a 2015 survey", Economic Alternatives,

Williams, C., Dzhekova, R., Baric, M., Franic,J. and Mishkov, L., (2014). Assessing the Cross-National Transferability of Policy Measures for Tackling Undeclared Work, GREY Working Paper No. 5, Sheffield University Management School, University of Sheffield

Williams, C.C., Dzhekova, R., Franic, J. and Mishkov, L. (2015) "Evaluating the policy approach towards the undeclared economy in FYR Macedonia", International Journal of Entrepreneurship and Small Business, Vol. 24, No. 2, pp.268-286.

Williams, C.C., Franic, J. and Dzhekova, R. (2014) "Explaining and tackling the undeclared economy in Bulgaria: an institutional asymmetry perspective", The South-East European Journal of Economics and Business, Vol. 9, No. 2, pp. 33-45. 


\section{Acknowledgements}

This Policy Brief is an output of the European Commission's Framework 7 Industry-Academia Partnerships Programme (IAPP) grant no. 611259 entitled 'Out of the shadows: developing capacities and capabilities for tackling undeclared work in Bulgaria, Croatia and FYR Macedonia' (GREY). The authors would like to thank the funders for providing the financial support to enable the research and writing of this policy brief. The usual disclaimers apply. We are grateful for the research support provided by Tzvetan Moev, University College, London, in the production of this policy brief. The findings are based on the data and research from the GREY project and are meant to aid policymakers in the region of Southeast Europe, and in particular in Bulgaria, Croatia and FYR of Macedonia, better understand and tackle undeclared work. 